\title{
Protozoa and digestive tract parameters of the impala
}

\author{
Authors: \\ Dirk G. Booyse ${ }^{1}$ \\ Burk A. Dehority ${ }^{2}$ \\ Affiliations: \\ ${ }^{1}$ Department of Anatomy \\ and Physiology, University of \\ Pretoria, South Africa \\ ${ }^{2}$ Department of Animal \\ Sciences, Ohio State \\ University, USA

\section{Correspondence to:} \\ Dirk Booyse \\ Email: \\ dbooyse@op.up.ac.za \\ Postal address: \\ Private Bag X04 \\ Onderstepoort 0110, \\ South Africa

\section{Dates:} \\ Received: 02 Mar. 2011 \\ Accepted: 23 May 2011 \\ Published: 12 Oct. 2011 \\ How to cite this article: \\ Booyse, D.G. \& Dehority, \\ B.A., 2011, 'Protozoa and \\ digestive tract parameters of \\ the impala', Onderstepoort \\ Journal of Veterinary \\ Research 78(1), Art. \#327, \\ 5 pages. doi:10.4102/ojvr. \\ v78i1.327
}

C 2011. The Authors. Licensee: AOSIS OpenJournals. This work is licensed under the Creative Commons Attribution License.
Intestinal contents were collected from eight impala at three different localities during the winter hunting season (2005-2009), as well as from another 24 animals from a one-year trial at a game farm called Ditholo (2003-2004). Gas production, protozoa counts and several other physiological parameters were measured from both rumen and caecum or colon contents. Only higher ophryoscolecid and Isotrichidae species of protozoa were counted and identified. Ostracodinium gracile was present in all 32 impala. Eudiplodinium maggii was present in 31 animals and Eudiplodinium impalae and Epidinium (either ecaudatum or caudatum) in 30 animals. Dasytricha ruminantium was present in only 11 of the impala. Concentrations of protozoa were correlated with the season of sample collection and highly correlated with the animals living on the game farm. Gas production ( $\mathrm{mL} / \mathrm{g}$ of wet rumen ingesta) was weakly correlated with protozoa concentration but not with the season of collection.

\section{Introduction}

A total of 13 protozoan species have previously been reported from the rumen of the impala. Dogiel (1925) listed six protozoan species from impala in Kenya and later, in 1932, he observed five species in Uganda. Four species were the same in both locations and the fifth belonged to the same genus but was identified as a different species (Table 1). In South Africa, Van der Wath and Myburgh (1941) reported the presence of three species in impala rumens and later Kleynhans (1977) recorded the presence of 11 species. Four of the species observed by Kleynhans, Isotricha prostoma, Entodinium paroum, Eudiplodinium maggii and Dasytricha ruminantium, were new host records for impala (see Table 1). Dehority and Odenyo (2003) identified protozoa in impala from Kenya only to the generic level and did not find any genera in which species had not previously been observed.

Apart from the counting and identification of protozoa, several other parameters of the digestive tract of the impala (rumen, small intestine, caecum and colon) were also investigated and are reported here for the first time. These include $\mathrm{pH}$ and temperature of contents, length of organ, contents weight per organ, gas production, dry matter and density.

\section{Materials and methods}

\section{Animals}

One female animal was collected from a farm called Karoobult, $100 \mathrm{~km}$ north-west of Pretoria $\left(24^{\circ} 43^{\prime} 49.45^{\prime \prime} \mathrm{S}, 2^{\circ} 33^{\prime} 22.88^{\prime \prime} \mathrm{E}\right)$, in July 2009, five animals (three male and two female) were from the Loskop Dam Nature Reserve in Mpumalanga province, $200 \mathrm{~km}$ east of Pretoria $\left(25^{\circ} 25^{\prime} 51.91^{\prime \prime S}\right.$, $\left.29^{\circ} 19^{\prime} 39.80^{\prime \prime} \mathrm{E}\right)$, and two male animals were from the Rietvlei Nature Reserve, $50 \mathrm{~km}$ south of Pretoria (2552'41.17'S, $\left.28^{\circ} 16^{\prime} 17.83^{\prime \prime} \mathrm{E}\right)$. In addition, 24 animals (all male) were from a one-year trial from the Ditholo game farm, $60 \mathrm{~km}$ north of Pretoria $\left(25^{\circ} 19^{\prime} 43.95^{\prime \prime} \mathrm{S}, 28^{\circ} 19^{\prime} 04.34^{\prime \prime} \mathrm{E}\right)$.

\section{Feed}

Impala are mixed feeders and therefore graze as well as browse. Feed available to the impala consists of vegetation types called bushvelds. A bushveld can be described as a heavily grassed plain, dotted by dense clusters of trees and tall shrubs. The grasses found here are generally tall and turn yellow or brown in winter, which is the dry season throughout most of South Africa. Sour bushveld consists of grazing fields, mostly comprising grasses like Eragrostis curvula, Eragrostis chloromelas, Hyparrhenia hirta and Cymbopogon excavatus. These grasses are fast-growing plants in the summer, but die rapidly in winter, turning hard and tasteless. Sour grass species can, however, recover quite rapidly from overgrazing. Sweet bushveld generally consists of grasses that grow slowly in summer but tend to stay highly nutritious and palatable during the dry season (winter). Sweet grass species include Digitaria eriantha, Panicum maximum and 
TABLE 1: Rumen protozoa observed from impala (Aepyceros melampus).

\begin{tabular}{|c|c|c|c|c|c|}
\hline Species & $\begin{array}{l}\text { Present study, } \\
\text { South Africa }\end{array}$ & $\begin{array}{c}\text { Van der Wath and } \\
\text { Myburgh (1941), } \\
\text { South Africa }\end{array}$ & $\begin{array}{l}\text { Kleynhans (1977), } \\
\text { South Africa }\end{array}$ & $\begin{array}{l}\text { Dogiel (1925), } \\
\text { Kenya }\end{array}$ & $\begin{array}{c}\text { Dogiel (1932), } \\
\text { Uganda }\end{array}$ \\
\hline Dasytricha ruminantium & $x$ & - & $x$ & - & - \\
\hline Entodinium dubardi & $x$ & - & $x$ & $x$ & $x$ \\
\hline Entodinium nanellum & $x$ & - & $x$ & $x$ & $x$ \\
\hline Entodinium parvum & $x$ & - & $x$ & - & - \\
\hline Eudiplodinium impalae & $x$ & - & $x$ & $x$ & $x$ \\
\hline Eudiplodinium maggi & $x$ & - & $x$ & - & - \\
\hline Eudiplodinium neglectum & - & - & $x$ & - & - \\
\hline Ostracodinium gracile & $x$ & - & $x$ & $x$ & $x$ \\
\hline Epidinium caudatum & $x$ & $x$ & $x$ & - & - \\
\hline Epidinium ecaudatum & $x$ & $x$ & $x$ & - & - \\
\hline Epiplastron spinosum & - & - & - & $x$ & $x$ \\
\hline
\end{tabular}

Note: Please see the full reference list of the article, Booyse, D.G. \& Dehority, B.A., 2011, 'Protozoa and digestive tract parameters of the impala', Onderstepoort Journal of Veterinary Research 78(1), Art. \#327, 5 pages. doi:10.4102/ojvr.v78i1.327, for more information.

Urochloa mosambicensis. Sweet grasses recover very slowly from heavy impacts like overgrazing. Mixed bushveld is a field composed of both sour and sweet grasses. The veld type in the Rietvlei and Ditholo areas is described as a sourish mixed bushveld, whilst Karoobult represents sour bushveld and the vegetation from the Loskop area is described as a mixed bushveld. In the spring and summer, impala both feed on grass (Eragrostis) and browse on trees like Acacia karoo and Acacia caffra. However, in the winter they are forced to 'low graze' on grass, as little or no browse is available.

\section{Measurements}

After shooting, the animals were weighed, the digestive tract removed and the different anatomical sections (rumen, small intestines, caecum and colon) were ligated before separation. Each section was weighed and the temperature, $\mathrm{pH}$ and length of the organs were measured and noted. Weights were measured with an electronic scale capable of measuring up to two decimal places and $\mathrm{pH}$ was measured with a portable, battery-powered $\mathrm{pH}$ meter (Eutech, model EC-PH$10 / 01 N$, Singapore). Organ content weights were estimated by weighing the organ full and empty.

Samples for fermentation studies $(200 \mathrm{~mL})$ were placed in fermentation vessels and gas production was measured every minute by means of a glass syringe (fitted with a 20-gauge stainless steel needle), inserted through the rubber stopper. Measurements were taken over a period of $45 \mathrm{~min}$. The exact weight of the samples was determined after complete fermentation.

\section{Protozoa}

A large sample of ingesta was taken from the rumen and the fluid squeezed out into a $40-\mathrm{mL}$ plastic specimen bottle. For the caecum and colon samples, small aliquots were taken at random from the contents and poured into the $40-\mathrm{mL}$ container. These samples were then transferred to larger marked containers and $100 \mathrm{~mL} \mathrm{70 \%} \mathrm{methanol} \mathrm{was} \mathrm{added}$ to each. Back at the laboratory, the protozoa samples were washed through sieves as described previously (Booyse, Boomker \& Dehority 2010). In essence, the entire sample was washed through a set of sieves with an inner and outer chamber. The sample was poured into the inner sieve (pore size $110 \mu \mathrm{m}$ ) and washed with water. Particulate matter and protozoa passed through to the outer sieve, which had a pore size of $37 \mu \mathrm{m}$. The outer sieve was fitted with a draining tap to allow the contents to be drained into a bottle. The washed sample was then allowed to stand for $30 \mathrm{~min}$ and the volume adjusted back to $40 \mathrm{~mL}$ by decanting the excess water. Two drops of Brilliant Green stain were added to each of the 40-mL samples, which were then allowed to stand for $24 \mathrm{~h}$ (Dehority 1984). Three aliquots (0.1 mL each) from each sample were placed onto separate microscope slides and fitted with a cover slip. Protozoa on each slide were counted using a standard light microscope fitted with a Panasonic digital camera (model GP220). Concentrations were determined by multiplying the mean of all three counts by 10 , thus giving a count per millilitre.

\section{Results and discussion Protozoa}

Initial examination of the protozoa samples revealed unexpectedly - a complete absence of Entodinium species. Subsequent investigation revealed that these species were washed out through the $37-\mu \mathrm{m}$ pores. The samples were washed primarily to remove most of the larger plant debris, which interferes with microscopical observation. Because all the samples had been washed, we were able to enumerate only Isotrichidae and the subfamilies Diplodiniinae and Ophryoscolecinae in the family Ophryoscolecidae (larger ophryoscolecid protozoa). However, we were able to shoot an additional impala, collect rumen contents, stain and count protozoa in a $0.1-\mathrm{mL}$ sample directly, without washing through sieves. Our examination revealed the presence of numerous Entodinium species in this last animal, which were identified and included with our previous data in Table 1. 
TABLE 2: Occurrence and concentration of Dasytricha ruminantium and larger ophryoscolecid protozoa in rumen contents of the impala.

\begin{tabular}{|c|c|c|c|c|c|c|c|c|c|}
\hline \multirow[t]{2}{*}{ Site } & \multicolumn{9}{|c|}{ Ophryoscolecid protozoa } \\
\hline & Number & Age $^{a}$ & $\operatorname{Sex}^{b}$ & $\begin{array}{l}\text { Dasytricha } \\
\text { ruminantium }\end{array}$ & $\begin{array}{c}\text { Ostracodinium } \\
\text { gracile }\end{array}$ & $\begin{array}{c}\text { Eudiplodinium } \\
\text { impalae }\end{array}$ & $\begin{array}{c}\text { Eudiplodinium } \\
\text { maggii }\end{array}$ & $\begin{array}{c}\text { Epidinium } \\
\text { ecaudatum }\end{array}$ & $\begin{array}{l}\text { Epidinium } \\
\text { caudatum }\end{array}$ \\
\hline Karoobuld & 1 & $A D$ & $\mathrm{~F}$ & - & - & - & - & - & - \\
\hline Concentration (Protozoa/mL) & - & - & - & - & 1200 & 1600 & - & - & - \\
\hline Rietvlei & 2 & $A D$ & M & - & - & - & - & - & - \\
\hline Occurrence (\%) & - & - & - & - & 100 & 100 & 100 & 50 & 100 \\
\hline & - & - & - & - & $(3360-4520)^{d}$ & $(4680-4920)^{d}$ & $(1180-1520)^{d}$ & - & $(3160-4160)^{d}$ \\
\hline \multirow[t]{2}{*}{ Loskop } & 3 & $A D$ & M & - & - & - & - & - & - \\
\hline & 2 & $A D$ & $\mathrm{~F}$ & - & - & - & - & - & - \\
\hline Occurrence (\%) & - & - & - & 20 & 100 & 100 & 100 & - & 80 \\
\hline \multirow[t]{2}{*}{ Concentration (Protozoa/mL) } & - & - & - & 200 & $1280 \pm 784^{c}$ & $520 \pm 440^{c}$ & $450 \pm 405^{c}$ & - & $750 \pm 810^{c}$ \\
\hline & - & - & - & - & $(400-2320)^{d}$ & $(80-1120)^{d}$ & $(80-1040)^{d}$ & - & $(40-1880)^{d}$ \\
\hline Ditholo & 24 & $A D$ & M & - & - & - & - & - & - \\
\hline \multirow[t]{2}{*}{ Concentration (Protozoa/mL) } & - & - & - & $1212 \pm 1826^{c}$ & $6469 \pm 5420^{c}$ & $1827 \pm 1720^{c}$ & $945 \pm 751^{c}$ & $200 \pm 143^{c}$ & $5371 \pm 5183^{c}$ \\
\hline & - & - & - & $(40-4160)^{d}$ & $(230-16640)^{d}$ & $(60-6440)^{d}$ & $(40-2760)^{d}$ & $(40-520)^{d}$ & $(20-17560)^{d}$ \\
\hline
\end{tabular}

a, $A D$, adult.

b, M, male; F, female

c, Mean value \pm STD.

, Range of values.

Four earlier reports on protozoa in the impala are also included in Table 1 for comparison. To date, 13 species of protozoa have been observed in the impala rumen. In South Africa, 11 of these were reported by Kleynhans in 1977, nine in the present study and three by Van der Wath and Myburgh in 1941. Dogiel reported a total of five species from impala in Kenya (1925) and Uganda (1932).

Table 2 reflects the occurrence and concentration of $D$. ruminantium and the larger ophryoscolecids (five species) as grouped by the collection site. Ostracodinium gracile was present in all 32 animals, E. maggii was present in 31 animals, whilst Eudiplodinium impalae and Epidinium caudatum were found in 30. In contrast, Epidinium ecaudatum was present in only 16 animals and Dasytricha species were found in nine. Thus, the majority of the larger ophryoscolecids were represented by four species, namely $O$. gracile, E. maggii, E. impalae and Ep. caudatum. The total concentration of all six species averaged about $1.6 \times 10^{4}$ per $\mathrm{mL}$ in the 24 animals from Ditholo, $0.32 \times 10^{4}$ per $\mathrm{mL}$ in the five from Loskop, $1.38 \times 10^{4}$ per $\mathrm{mL}$ in the two impala from Rietvlei and $0.28 \times$ $10^{4}$ per $\mathrm{mL}$ in the single animal from Karoobult.

The caecum and colon contents were mixed, washed as described above, and examined microscopically for protozoa. The results in Table 3 show that only very low concentrations were present in the ingesta from these organs. Presumably, the protozoa would be digested as they move through the abomasum and small intestine; however, some cells are obviously able to pass through unharmed. It is possible that they are embedded in larger food particles and are not exposed to the acidic and enzymatic conditions in those organs. These concentrations are considerably higher than what one author (B.A.D.) has previously observed in domestic ruminants (unpublished).
A possible relationship between the time (i.e. the month when the animal was harvested) and the concentration of the larger protozoa was investigated, taking all 32 animals into consideration. A correlation coefficient $(r)$ of 0.65 was obtained $\left(r^{2}=0.42\right)$. However, when only the 24 animals from a single location (Ditholo) were used, the correlation coefficient was $0.865\left(r^{2}=0.75\right)$. Figure 1 shows the regression of protozoa concentration for all 32 animals, according to time of harvesting. The first sample was obtained in December and labeled as 0 , followed by January as 1, February as 2, etc. This was based on the assumption that the start of the summer growing season would begin in December, when pasture and browse were low, and that feed would become increasingly available during the following months.

It is also of interest that only two genera of the subfamily Diplodiniinae, Eudiplodinium and Ostracodinium, have been

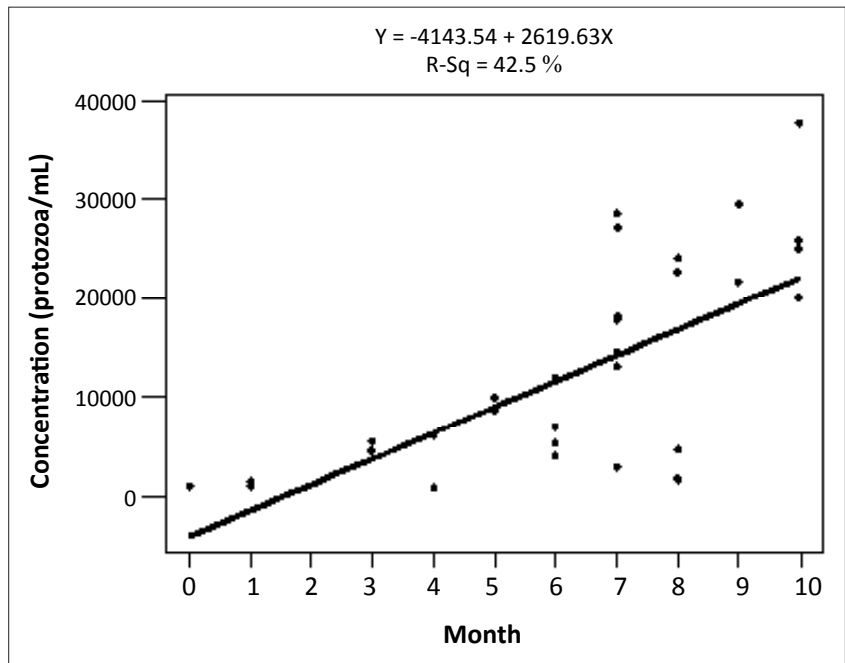

Months shown on x-axis run from December (0) to October (10).

FIGURE 1: Regression of concentration of the larger protozoa in impala rumen contents according to the month of collection. 
TABLE 3: Occurrence and concentration of Dasytricha ruminantium and larger ophryoscolecid protozoa in the caecum or colon contents of impala.

\begin{tabular}{|c|c|c|c|c|c|c|c|c|c|}
\hline \multirow[t]{2}{*}{ Site } & \multicolumn{9}{|c|}{ Ophryoscolecid protozoa } \\
\hline & Number & Age $^{a}$ & $\operatorname{Sex}^{b}$ & $\begin{array}{l}\text { Dasytricha } \\
\text { ruminantium }\end{array}$ & $\begin{array}{l}\text { Ostracodinium } \\
\text { gracile }\end{array}$ & $\begin{array}{l}\text { Eudiplodinium } \\
\text { impalae }\end{array}$ & $\begin{array}{l}\text { Eudiplodinium } \\
\text { maggii }\end{array}$ & $\begin{array}{l}\text { Epidinium } \\
\text { ecaudatum }\end{array}$ & $\begin{array}{l}\text { Epidinium } \\
\text { caudatum }\end{array}$ \\
\hline Karoobuld & 1 & $A D$ & $\mathrm{~F}$ & - & - & - & - & - & - \\
\hline Occurrence $(\%)$ & - & - & - & - & 100 & 100 & - & - & - \\
\hline Concentration (Protozoa/mL) & - & - & - & - & 180 & 50 & - & - & - \\
\hline Rietvlei & 2 & $A D$ & M & - & - & - & - & - & - \\
\hline Occurrence (\%) & - & - & - & - & - & - & 100 & - & - \\
\hline Concentration (Protozoa/mL) & - & - & - & - & - & - & $40 \pm 0^{c}$ & - & - \\
\hline \multirow[t]{2}{*}{ Loskop } & 3 & $A D$ & M & - & - & - & - & - & - \\
\hline & 2 & $A D$ & $\mathrm{~F}$ & - & - & - & - & - & - \\
\hline Occurrence (\%) & - & - & - & - & 60 & 60 & 60 & - & 60 \\
\hline \multirow[t]{2}{*}{ Concentration (Protozoa/mL) } & - & - & - & - & $50 \pm 26^{c}$ & $63 \pm 29^{c}$ & $83 \pm 31^{c}$ & - & $163 \pm 132^{c}$ \\
\hline & - & - & - & - & $(30-80)^{d}$ & $(30-80)^{d}$ & $(50-110)^{d}$ & - & $(20-280)^{d}$ \\
\hline Ditholo & 24 & $A D$ & M & - & - & - & - & - & - \\
\hline Occurrence $(\%)$ & - & - & - & 4 & 75 & 42 & 42 & 8 & 50 \\
\hline \multirow[t]{2}{*}{ Concentration (Protozoa/mL) } & - & - & - & 60 & $88 \pm 84^{c}$ & $61 \pm 70^{c}$ & $38 \pm 30^{c}$ & $15 \pm 7^{c}$ & $58 \pm 50^{c}$ \\
\hline & - & - & - & - & $(30-360)^{d}$ & $(10-220)^{d}$ & $(20-120)^{d}$ & $(10-20)^{d}$ & $(10-160)^{d}$ \\
\hline
\end{tabular}

a, $A D$, adult.

, M, male; F, female.

Mean value \pm ST

Range of values.

TABLE 4: Physiological parameters of the impala digestive tract and gas production by rumen, caecum and colon contents.

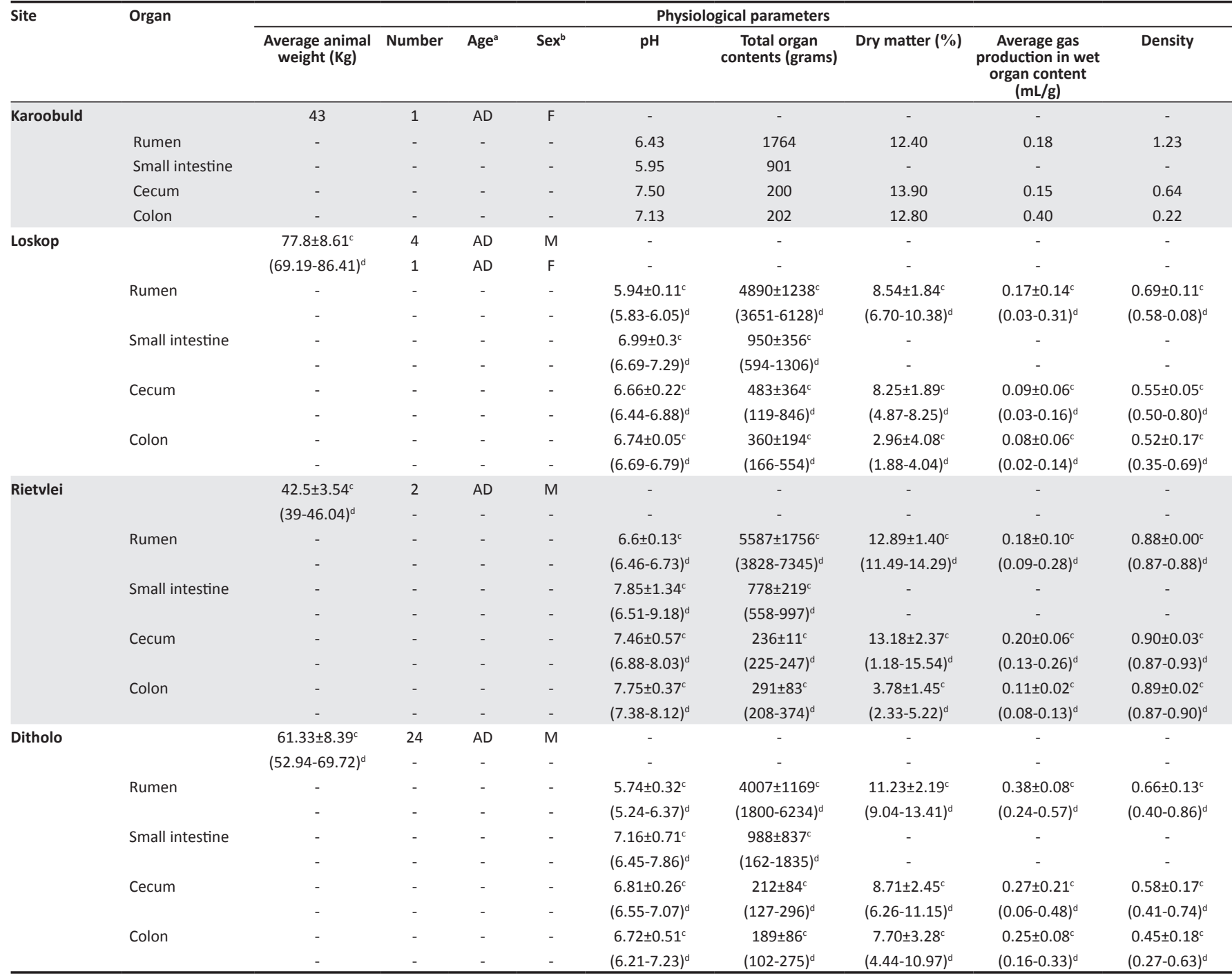

Range of values. 
found in the impala. Species of Diplodinium, Metadinium, Enoploplastron, Elytroplastron and Polyplastron occur in many of the other wild ruminants in Africa (Dehority \& Odenyo 2003; Dogiel 1925, 1932; Kleynhans \& Van Hoven 1975; Van Hoven 1975, 1978, 1983).

\section{Physiological parameters}

Table 4 presents information on the collection site, age, sex, organ $\mathrm{pH}$, weight of the organ contents, percentage dry matter, density and gas production from organ contents, incubated in vitro (gas production was not measured with small intestine ingesta). Except for the animal from Karoobult and the two from Rietvlei, rumen $\mathrm{pH}$ values averaged below 6.0. This value would be expected in grazing ruminants, as demonstrated in the study by Dehority and Tirabasso (2001), where sheep were fed 1, 6, or 24 times per day. Rumen dry matter values fell within the normal reported range of $10 \%-$ 13\% (Dehority 2003).

The aim of measuring gas production was to evaluate whether this parameter was associated with protozoal concentrations. When gas production was correlated with numbers of larger protozoa, the correlation coefficient was 0.31 , indicating little or no association. This is not entirely unexpected, because a number of factors would be involved. Probably the most critical would be the amount of available substrate in the rumen contents, regardless of the concentration of protozoa and bacteria. Gas production from rumen, caecum and colon contents was greater in the animals on the game farm, suggesting that more substrate was available in the ingesta from these animals than from those living in the bushveld. In future studies it would be desirable to measure fermentation capacity as described by El-Shazley and Hungate (1965), where additional substrate is added.

Temperature of organ contents ranged from $30^{\circ} \mathrm{C}$ to $41^{\circ} \mathrm{C}$ for the rumen, between $11{ }^{\circ} \mathrm{C}$ and $28^{\circ} \mathrm{C}$ for the small intestine, between $17{ }^{\circ} \mathrm{C}$ and $31{ }^{\circ} \mathrm{C}$ for the caecum and between $13{ }^{\circ} \mathrm{C}$ and $30{ }^{\circ} \mathrm{C}$ for the colon. Length of the organs ranged from $281 \mathrm{~mm}$ to $570 \mathrm{~mm}$ for the rumen, $6218 \mathrm{~mm}$ to $13852 \mathrm{~mm}$ for the small intestine, $162 \mathrm{~mm}$ to $652 \mathrm{~mm}$ for the caecum, and $190 \mathrm{~mm}$ to $1411 \mathrm{~mm}$ for the colon (data not shown).

\section{Conclusion}

The number of genera and species of protozoa occurring in the impala is limited compared to other African wild ruminants and domesticated cattle and sheep (Booyse \& Dehority in press; Dehority \& Odenyo 2003; Dogiel 1932; Kleynhans \& Van Hoven 1976; Van Hoven 1975, 1978, 1983). Only four species of Entodinium, two genera of Diplodiniinae and two species of Epidinium have been observed.

\section{Acknowledgements Authors' contributions}

D.G.B. collected the samples, was responsible for all the measurements and conducted the microscopic studies. B.A.D. assisted with identification of the species, compilation of the data and writing the manuscript.

\section{References}

Booyse, D.G. \& Dehority, B.A., in press, 'Rumen protozoa in South African sheep with a summary of the worldwide distribution of sheep protozoa', Onderstepoort Journal of Veterinary Research. PMCid:2628563

Booyse, D.G., Boomker, E.A. \& Dehority, B.A., 2010, 'Protozoa in the digestive tract of wild herbivores in South Africa. I: Warthogs (Phacochoerus aethiopicus)', Zootaxa 2492, 63-68.

Dehority, B.A., 1984, 'Evaluation of sub-sampling and fixation procedures used for counting rumen protozoa', Applied and Environmental Microbiology 48, 182-185. PMid:6476828, PMCid:240360

Dehority, B.A., 2003, Rumen Microbiology, Nottingham University Press, Nottingham, UK.

Dehority, B.A. \& Odenyo, A.A., 2003, 'Influence of diet on the rumen protozoal fauna of indigenous African wild ruminants', Journal of Eukaryotic Microbiology 50, of indigenou.

Dehority, B.A. \& Tirabasso, P.A., 2001, 'Effect of feeding frequency on bacterial and fungal concentrations, $\mathrm{pH}$ and other parameters in the rumen', Journal of Animal Science 79, 2908-2912. PMid:11768121

Dogiel, V., 1925, 'Nouveaux infusoires de la famille des Ophryoscolécidés parasites d'antilopes Africaines' [New infusoria of the family of ophryoscolecid parasites in African antelope], Annales de Parasitologie 2, 116-142.

Dogiel, V., 1932, 'Beschreibung einiger neuer Vertreter der Familie Ophryoscolecidae aus afrikanischen Antilopen nebst Revision der Infusorienfauna afrikanische Wiederkäuer' [Description of some new representatives of the family Ophryoscolecidae from African antelope together with a revision of the infusorial fauna of African ruminants], Archiv für Protistenkunde 77, 92-107.

El-Shazley, K. \& Hungate, R.E., 1965, 'Fermentation capacity as a measure of net growth of rumen organisms', Applied Microbiology 13, 62-69. PMid:14269247, PMCid:1058191

Kleynhans, C.J., 1977, 'The rumen protozoa of the impala (Aepyceros melampus) Lichtenstein, and the kudu (Tragelaphus strepsiceros) Pallas', PhD thesis, Department of Zoology, University of Pretoria.

Kleynhans, C.J. \& Van Hoven, W., 1976, 'Rumen protozoa of the giraffe with a description of two new species', East African Wildlife Journal 14, 203-214.

Van der Wath, J.G. \& Myburgh, S.J., 1941, 'Studies on the alimentary tract of merino sheep in South Africa. VI. The role of infusoria in ruminal digestion with some remarks on ruminant bacteria', Onderstepoort Journal of Veterinary Science and Animal Industry 17, 61-85.

Van Hoven, W., 1975, 'Rumen ciliates of the Tsessebe (Damaliscus lunatus lunatus) in South Africa', Journal of Protozoology 22, 457-462. PMid:811788

Van Hoven, W., 1978, 'Development and seasonal changes in the rumen protozoan population in young blesbok (Damaliscus dorcas Phillipsi Harper 1939)', South African Journal of Wildlife Research 8, 127-130.

Van Hoven, W., 1983, 'Rumen ciliates with descriptions of two new species from three African reedbuck species', Journal of Protozoology 30, 688-691. 